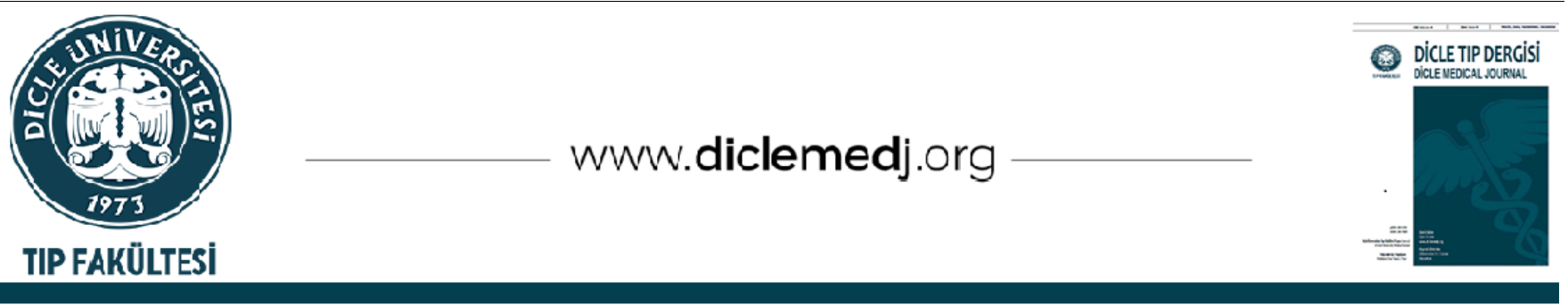

Original Article / Özgün Araştırma

\title{
What Is The Need For Repeat Angiography In Spontaneous Subarachnoid Hemorrhages With Negative Initial Angiogram?
}

\author{
Abdullah Topcu ${ }^{\text {iD }}$, Ayca Ozkul ${ }^{D_{2}}$ \\ 1 Adnan Menderes University, Faculty of Medicine, Neurosurgery Department Aydın, Turkey \\ 2 Adnan Menderes University, Faculty of Medicine, Neurology Department, Aydin Turkey \\ Received: 02.10.2020; Revised: 11.01.2021; Accepted: 23.01.2021
}

\begin{abstract}
Objective: Repeat angiography is usually performed in spontaneous SAH patients who have negative initial angiography. In this study we aimed to evaluate the yield of repeat angiography in spontaneous SAH with different clinics and bleeding paterns.
\end{abstract}

Methods: A retrospective analysis was performed on spontaneous SAH patients who admitted to our neurosurgery clinic. The patients were divided into two groups as perimesencephalic and nonperimesencephalic SAH according to their bleeding patern on cerebral CT. Demographic and clinic data, routine follow-up cerebral angiography within 2 weeks, complications due to repeated cerebral angiography and the presence of new detected vascular pathology were all recorded.

Results: 208 patients with spontaneous SAH with mean age 60.00 $\pm 15.82(20-83)$ years were included. The Fisher score was found lower in perimesencephalic SAH patients. Mortality was also seen more frequently in nonperimesencephalic $\mathrm{SAH}$. In repeat angiography vascular pathology related with SAH was found in only nonperimesencephalic SAH patients without any statistically significancy ( 0 vs $4, p: 0.078$ ). The incidence of complications due to repeat angiography was similiar in both groups.

Conclusion: In conclusion clinicians should consider to evaluate the spontaneous SAH with subsequent neuroimaging tests once more to rule out cerebral vascular pathologies. Our data suggested that perimesencephalic SAH has a better Fisher score and less mortality when compared with nonperimesencephalic SAH. Our perimesencephalic SAH patients have no vascular pathology even after repeat angiography. Therefore high quality MR angiography or CTangiography can be easily performed rather than cerebral angiography which is an invasive imaging method. Cerebral angiography should be considered only in suspected cases with perimesencephalic SAH.

Keywords: subarachnoid hemorrhage; cerebral angiography; bleeding; aneurysm; neuroimaging.

DOI: 10.5798/dicletip.887371

Correspondence / Yazışma Adresi: Ayça Özkul, Adnan Menderes University, Faculty of Medicine Department of Neurology Aydin, Turkey e-mail: ozkulayca@hotmail.com 


\section{İlk Anjiografisi Negatif Olan Spontan Subaraknoid Kanamalarda Anjiografi Tekrarının Gereksinimi Nedir?}

Öz

Amaç: Bu çalışmanın amacl, obstetrik nedenli dissemine intravasküler kuagülasyonun (DİK) altta yatan nedenlerini araştırmak ve Giriş: Tekrar anjiografi ilk anjiografisi negatif olan spontan subaraknoid kanamalı (SAK) hastalarda genelde uygulanır. Bu çalışmada tekrar anjiografinin gerekliliğini farklı klinik ve kanama paterni olan spontan SAK'larda incelemeyi amaçladık.

Yöntemler: Nöroşirurji Kliniğimize başvuran spontan SAK hasta verileri üzerinden retrospektif analiz yapıldı. Hastalar perimesensefalik ve nonperimesensefalik SAK olarak serebral BT'de kanama paternlerine göre iki gruba ayrıldı. Demografik, klinik veri, rutin iki hafta içinde uygulanan izlem serebral anjiografiler, anjiografi tekrarına bağlı komplikasyonlar ve yeni saptanan vaskuler patoloji varlığı kaydedildi.

Bulgular: 208 spontan SAK hastası ortalama yaş 60.00 15.82 (20-83) dahil edildi. Fisher skoru perimesensefalik SAK hastalarında daha düşük elde edildi. Mortalite de nonperimesensefalik SAK hastalarda daha sık izlenildi. SAK ile ilişkili vaskuler patoloji sadece nonperimesensefalik SAK hastalarında istatistiksel farklllık olmaksızın izlenildi (0 vs 4, p:0.078). Anjiografi tekrarına bağlı komplikasyon insidansı her iki grupta benzerdi.

Sonuç: Klinisyenler spontan SAK'ta serebral vaskuler patolojileri bir kere daha dışlamak amacıyla ardışık nörogörüntüleme testleri düşünmelidir. Verilerimiz nonperimesensefalik ile kıyaslandığında perimesensefalik SAK'larda Fisher skorunun daha iyi ve daha az mortal olduğunu desteklemektedir. Perimesensefalik SAK hastalarımızın anjiografi tekrarlarında herhangi vaskuler patoloji yoktu. Bu nedenle bu hastalarda invazif bir görüntüleme metodu olan serebral anjiografi yerine yüksek kalitede MRanjiografi veya BTanjiografi daha kolay uygulanabilir. Serebral anjiografi sadece şüphelenilen perimesensefalik SAKlarda düşünülebilir.

Anahtar kelimeler: subaraknoid hemoraji; serebral anjiografi; kanama; anevrizma; nörogörüntüleme.

\section{INTRODUCTION}

Subarachnoid hemorrhage is a serious health problem usually caused by a rupture of a cerebral aneurysm. No obvious source of bleeding can be identified in up to $15 \%$ (range, 5-34\%) of patients with spontaneous SAH, despite further neuroradiological investigations including four-vessel cerebral digital subtraction angiography (DSA) which is still the gold standart for diagnosing cerebral vascular anomaly ${ }^{1,2}$. In these patients the clinic is much better and there is a low risk of rebleeding when compared with SAH due to cerebral aneurysm ${ }^{3,4}$. However there is a need of more data about SAH with negative initial DSA. Cerebral vasospasm, vascular thrombosis, obliteration of the aneurysm by an adjacent hematoma, bleeding amount and quality of cerebral DSA may cloak the presence of vascular anomaly, therefore patients with negative initial angiogram usually undergo additional vascular studies during follow up. The further investigations may be helpfull for achieving a definite diagnosis ranges from 2 to $20 \%$ which is quite wide ${ }^{1,5,6}$. Although cerebral DSA is the commonly used reliable diagnotic approach in $\mathrm{SAH}$, it should't be forgotten that DSA is an invasive method and needs hospitalization with a risk of persistent neurologic deficit. Therefore clinicians should scrutiny the patients with negative initial DSA and decide whether repeat DSA is inevitable or not for further diagnostic approach

In this study, we investigated the demographic data, clinical features and cerebral DSA findings of our SAH patients whose initial DSA was negative. Additionally, bleeding patern and Fisher scores were also evaluated.

\section{METHOD}

This is a retrospective study of 728 patients with SAH who were admitted to the 
Neurosurgery Department between January 2016 and December 2019. The diagnosis of SAH was done according to noninvasive neuroimaging studies including computed tomography (CT), magnetic resonance imaging (MRI), CT angiography (CTA) and MR angiography (MRA). Afterwards patients underwent cerebral DSA procedure which was performed in the angiography suite by an endovascular neurosurgeon within 2-48 hours (mean $5.9 \pm 0.97 \mathrm{~h}$ ). Selective catheterization of the internal and external carotid arteries, vertebral, or subclavian arteries was performed in order to visualize the vascular pathology. We diagnosed 208 patients as spontaneous SAH with negative initial DSA and included in our study. The patients with hemorrhagic diathesis, renal insufficiency and contrast allergy were excluded since cerebral DSA could not be performed. Demographic data were recorded and the patients were analyzed according to the Fisher scores. The patients were also evaluated according to neuroimaging findings and classified as perimesencephalic or nonperimesencephalic based on the hemorrhage distribution pattern. Every patient had a routine follow-up cerebral DSA within 2 weeks after the initial negative DSA. Complications due to repeated cerebral DSA and the presence of vascular pathology (cerebral aneurysm, arteriovenous malformation, intracranial vasculitis, cerebral vasoconstriction, mycotic aneurysms and a shunting vascular malformation) detected in the repeat cerebral DSA were all recorded. This study was approved by our local ethic committee $(2020 / 151)$.

\section{Statistical Analyses}

All statistical analyses were performed with SPSS 16.0 for Windows (SPSS Inc., Chicago, IL). Group comparisons were performed with Student's ttest for normally distributed continuous variables or Mann-Whitney U test for other continuous variables. Multiple mean comparisons were analyzed by one-way ANOVA, and $\mathrm{p}<0.05$ was considered statistically significant.

\section{RESULTS}

A total of 208 patients ( 92 females and 116 males) with spontanenous $\mathrm{SAH}$ were included in this study. The mean age of the patients was $60.00 \pm 15.82(20-83)$ years. The patients were divided into two groups as having either perimesencephalic $\quad(n: 118) \quad$ or nonperimesencephalic SAH (n:90) (Figure 1a, 1b). The demographic characteristics and the clinical profiles of patients are shown in Table1. The Fisher score was found lower in perimesencephalic SAH patients. Mortality was also seen more frequently in nonperimesencephalic SAH patients (p: 0.01). The incidence of pathological findings which was found in repeat cerebral DSA was also recorded. Repeat DSA yielded abnormal findings in 4 $(4.44 \%)$ of the patients with nonperimesencephalic SAH. Although none of the perimesencephalic SAH patients had new pathological findings in their control cerebral DSA, this didn't cause statistical difference in comparison of two groups (p: 0.078). The other studied parameter was the incidence of complications due to DSA and no statistical difference was found (Table 1).

Table I: The comparison of perimesencephalic and nonperimesencephalic SAH patients

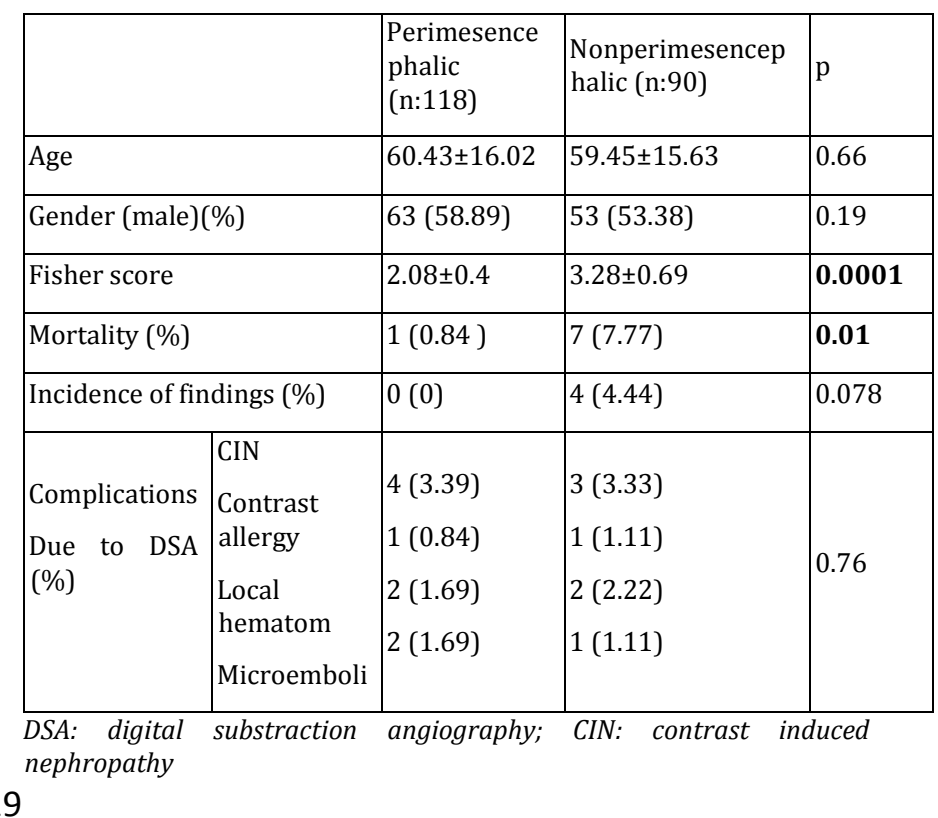




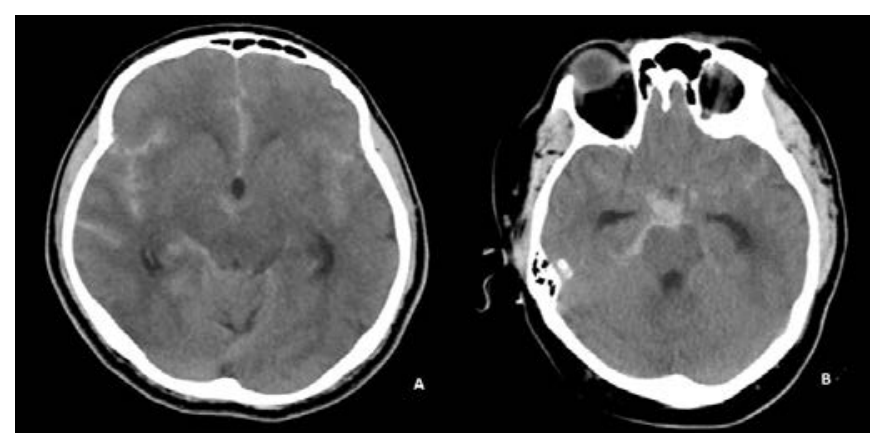

Figure1: Cerebral CT demonstrating blood pattern of nonperimesencephalic (A) and perimesencephalic SAH (B)

\section{DISCUSSION}

In literature it has been previously reported as initial angiographic findings are negative for a bleeding source in $15-20 \%$ of patients ${ }^{2,7,8}$. It is wellknown that spontaneous SAH without any source of bleeding carries a more benign prognosis than aneurysmal SAH. However the vascular pathology causing SAH cannot be always detected in the initial cerebral DSA. In literature repeat catheter angiography is recommended in the evaluation of $\mathrm{SAH}$ with negative initial DSA, demonstrating a causative vascular abnormality ${ }^{9}$. Therefore a repeat cerebral DSA within 2 weeks after SAH onset is commonly performed and in this way the source of bleeding can be detected in $15-20 \%$ of patients. This is also important in the treatment strategy of SAH patients 1 . Some patients may experience rebleeding and vasospasm which may cause poor outcome or even mortality which requires furter investigation such as repeat cerebral DSA. We summarized our algorithm of clinical approach to spontaneous SAH patients in Figure 2.

The type and location of aneurysms identified on repeat cerebral DSA are also important. They are mainly saccular and very small in size $(<2 \mathrm{~mm})(9)$. In our study we found 4 aneurysms in repeat cerebral DSA examination of nonperimesencephalic SAH patients. 2 of them was located in distal M1 segment of MCA and were blisterlike aneurysms. The other 2 of them was in intracranial segment of ICA with large neck and small diameter in size $(<2 \mathrm{~mm})$.

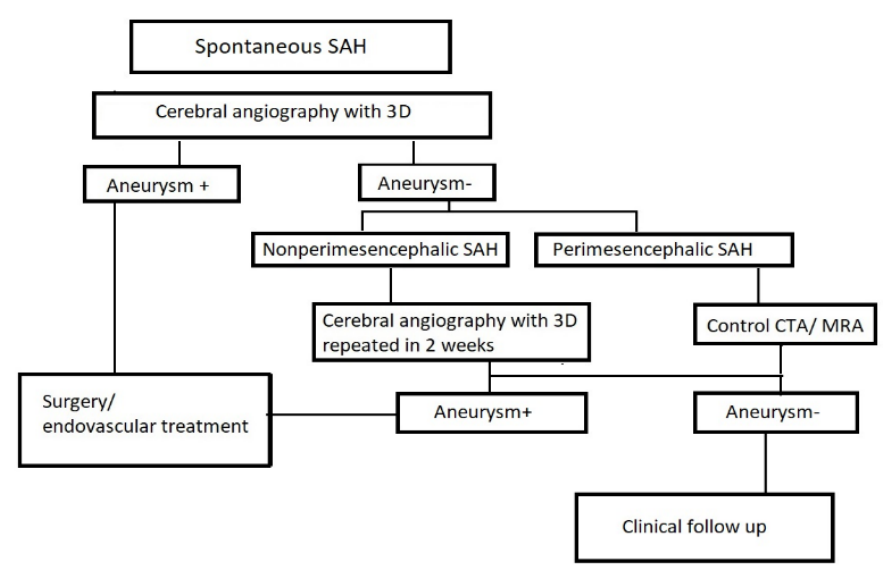

Figure 2: The algorithm demonstrating the neuroimaging approach in spontaneous SAH patients.

We also believe that cerebral DSA technique is important in detecting vascular pathologies especially in SAH with negative initial cerebral DSA. Performing rotational angiography with $3 \mathrm{D}$ reconstructions add a value to planar images and provides neurointerventionist to detect the vascular pathology clear. Although it is often hard to obtain high-quality rotational angiography with 3D reconstructions in acute $\mathrm{SAH}$, in repeat cerebral DSA this can be more easily done.

The frequency of patients with negative initial cerebral DSA in our study (3.38\%) is lower than previously reported data by Delgado Almandoz et al $(6 \%)$ and Hashimoto et al $(11.2 \%)^{7,9}$. This may be due to the accurancy of initial cerebral DSA. We often prefer performing rotational angiography with 3D reconstructions in all acute SAH patients. Additionally in unconscious and agitated patients we often use conscious sedation with the help of anesthesiologist. Therefore movement artefacts are less than as expected.

In repeat cerebral DSA of perimesencephalic $\mathrm{SAH}$ patients we found no pathology. It is also 
wellknown that perimesencephalic SAH has better outcome and usually there is no source of bleeding. However clinicians should keep in mind that SAH due to vascular pathologies of anterior circulation of brain may resemble perimesencephalic SAH. Additionally, 10-16\% of patients with ruptured aneurysms of the posterior circulation may be presented with perimesencephalic SAH and this may need corfirming in repeat cerebral DSA ${ }^{3,10,11}$. Therefore perimesencephalic bleeding pattern may constitte a false localizing sign of SAH. This brings out the need of scrutiny in patients with perimesencephalic SAH.

We couldnot detect any vascular pathologies in repeat cerebral DSA of perimesencephalic SAH patients. Therefore we should discuss the diagnostic approach in subsequent investigation. We believe that in perimesencephalic SAH patients clinicians may consider MRA or CTA in control examination. Cerebral DSA is an invasive method and has more complications than noninvasive imaging modalities. We had complications due to cerebral DSA in $7.69 \%$ of our patients. All of them were transient and didn't cause any more serious health problems. However we should consider the real need of DSA as an invasive method. Ruigrok et al. also concluded that the best diagnostic approach for perimesencephalic SAH is CTA $^{12}$. Additionally MR SWI sequence can be used in detection of macro-micro bleeding ${ }^{13}$.

In conclusion clinicians should consider to evaluate the spontaneous SAH patients once more to rule out aneurysmal SAH which may cause serious rebleeding. Therefore we prefer performing repeat cerebral DSA within 2 weeks after presentation of SAH. We also believe that the bleeding pattern on CT scans has prognostic value in patients with spontaneous SAH. We found that perimesencephalic SAH has a better Fisher score and less mortality when compared with nonperimesencephalic SAH patients.
Additionally in our study perimesencephalic SAH patients have no vascular pathology even after repeat cerebral DSA and therefore we believe that high quality MRA or CTA can be performed rather than cerebral DSA which is an invasive imaging method with transient complications including contrast induced nephropathy, contrast allergy, microemboli and local hematom. We believe that cerebral DSA should be considered only in suspected perimesencephalic SAH with negative subsequent noninvasive neuroimaging studies such as MRA and CTA. We also found less positive repeat cerebral DSA than literature. The role of 3D rotational DSA appears promising even in the initial cerebral DSA but remains to be defined.

Ethics Committee Approval: This study was approved by our local ethic committee (2020/151).

Declaration of Conflicting Interests: The authors declare that they have no conflict of interest.

Financial Disclosure: No financial support was received.

\section{REFERENCES}

1. Andaluz N, Zuccarello M. Yield of further diagnostic work-up of cryptogenic subarachnoid hemorrhage based on bleeding patterns on computed tomographic scans. Neurosurgery. 2008 May; 62: 1040-6.

2. Alén JF, Lagares A, Lobato RD, et al. Comparison between perimesencephalic nonaneurysmal subarachnoid hemorrhage and subarachnoid hemorrhage caused by posterior circulation aneurysms. J Neurosurg 2003; 98: 529-35

3. Ildan F, Tuna M, Erman T, et al. Prognosis and prognostic factors in nonaneurysmal perimesencephalic hemorrhage: a follow-up study in 29 patients. Surg Neurol 2002; 57: 160-5.

4. Yllmaz A, Özkul A. Demographic and clinical features of subarachnoid hemorrhages with or 
without cerebral aneurysm. Turkish Journal of Cerebrovascular Diseases 2017; 23: 56-61.

5. Little AS, Garrett M, Germain R, et al. Evaluation of patients with spontaneous subarachnoid hemorrhage and negative angiography. Neurosurgery. 2007; 61: 1139-50.

6. Agid R, Andersson T, Almqvist H, et al. Negative CT Angiography findings in patients with spontaneous subarachnoid hemorrhage: when is digital subtraction angiography still needed? AJNR Am J Neuroradiol. 2010; 31: 696-705.

7. Hashimoto H, Iida J, Hironaka Y, Okada M, Sakaki $\mathrm{T}$ : Use of spiral computerized tomography angiography in patients with subarachnoid hemorrhage in whom subtraction angiography did not reveal cerebral aneurysms. J Neurosurg 2000; 92: 278-83.

8. Ildan F, Tuna M, Erman T, Göcer AI, Cetinalp E. Prognosis and prognostic factors in nonaneurysmal perimesencephalic hemorrhage: A follow-up study in 29 patients. Surg Neurol. 2002; 57: 160-6.
9. Delgado Almandoz JE, Jagadeesan BD, Refai D, et al. Diagnostic yield of repeat catheter angiography in patients with catheter and computed tomography angiography negative subarachnoid hemorrhage. Neurosurgery.2012May; 70: 1135-42.

10. Ildan F, Tuna M, Erman T, et al. Prognosis and prognostic factors for unexplained subarachnoid hemorrhage: Review of 84 cases.Neurosurgery 2002; 50: 1015-25.

11. Inamasu J, Nakamura Y, Saito R, et al. "Occult" ruptured cerebral aneurysms revealed by repeatangiography: Result from a large retrospective study. Clin Neurol Neurosurg.2003; 106: 33-7.

12. Ruigrok YM, Rinkel GJ, Buskens E, Velthuis BK, van Gijn J. Perimesencephalic hemorrhage and CT angiography. A decision analysis. Stroke.2000; 31: 2976-83.

13. Teke M, Kına A, Sarıca Ö, Albayram S. Susceptibility Weighted Imaging sequence applications in neuroradiology . Dicle Med J 2015; 42: 235-41. 